\title{
PERSPECTIVE
}

\section{Exile Literature and the Diasporic Indian Writer}

\author{
Amit Shankar Saha \\ Calcutta University, West Bengal, India
}

\begin{abstract}
The essay takes a holistic view of the word "exile" to encompass a range of displaced existence. It illustrates through John Simpson's The Oxford Book of Exile the various forms of exiles. The essay then goes on to show that diasporic Indian writing is in some sense also a part of exile literature. By exemplifying writers both from the old Indian diaspora of indentured labourers and the modern Indian diaspora of IT technocrats, it shows that despite peculiarities there is an inherent exilic state in all dislocated lives whether it be voluntary or involuntary migration. More importantly, a broad survey of the contributions of the second generation of the modern Indian diaspora in the field of Indian writing in English depict certain shift in concerns in comparison to the previous generation and thereby it widens the field of exile literature.
\end{abstract}

Displacement, whether forced or self-imposed, is in many ways a calamity. Yet, a peculiar but a potent point to note is that writers in their displaced existence generally tend to excel in their work, as if the changed atmosphere acts as a stimulant for them. These writings in dislocated circumstances are often termed as exile literature. The word "exile" has negative connotations but if the self-exile of a Byron is considered, then the response to that very word becomes ambivalent. If a holistic view of the word "exile" is taken, the definition would include migrant writers and non-resident writers and even gallivanting writers who roam about for better pastures to graze and fill their oeuvre. World literature has an abundance of writers whose writings have prospered while they were in exile. Although it would be preposterous to assume the vice-versa that exiled writers would not have prospered had they not been in exile, the fact in the former statement cannot be denied. Cultural theorists and literary critics are all alike in this view.

The study of world literature might be the study of the way in which cultures recognize themselves through their projections of 'otherness.' Where, once, the transmission of national traditions was the major theme of a world literature, perhaps we can now suggest that transnational

\footnotetext{
Rupkatha Journal on Interdisciplinary Studies in Humanities (ISSN 0975-2935)

Volume I, Number 2, Autumn 2009

URL of the Issue: www.rupkatha.com/journalvol1no2.php

PHP URL of the article: www.rupkatha.com/exileliteraturethediasporicindianwriters.php

PDF URL of the article: www.rupkatha.com/0102exileliteratureanddiasporicindianwriter.pdf

(C) www.rupkatha.com
} 
histories of migrants, the colonized, or political refugees - these border and frontier conditions - may be the terrains of world literature. (Bhabha 12)

The diasporic production of cultural meanings occurs in many areas, such as contemporary music, film, theatre and dance, but writing is one of the most interesting and strategic ways in which diaspora might disrupt the binary of local and global and problematize national, racial and ethnic formulations of identity.(Ashcroft 218)

The multivoiced migrant novel gave vivid expression to theories of the "open" indeterminate text, or of transgressive, non-authoritative reading. (Boehmer 243)

In an interview with Nikhil Padgaonkar for Doordarshan, Edward W. Said reflected on the condition of exile:

I think that if one is an intellectual, one has to exile oneself from what has been given to you, what is customary, and to see it from a point of view that looks at it as if it were something that is provisional and foreign to oneself. That allows for independence-commitment-but independence and a certain kind of detachment. (Said 13)

John Simpson in The Oxford Book of Exile writes that exile "is the human condition; and the great upheavals of history have merely added physical expression to an inner fact" (Simpson "Introduction"). Indeed it is so if exile is taken to be identical with self-alienation in the modern, post-Marxist, Brechtian sense of the term. Physical mobility often heightens the spiritual or psychological sense of alienation from the places one continually moves between. The world, in existentialist terms, appears absurd and indifferent towards one's needs. In such a situation one cannot help but feel like an outsider. Therefore, it is well agreed that exile is a part of the human experience. Many a Shakespearean play has in it exile in the form of banishment and it dates back even before the time of Pericles of Athens. As for writers of yore there is Ovid whose hyperbolic lamentation on being exiled from Rome for publishing an obscene poem forms part of his Tristia I. There is Virgil whose Aeneas leaves Troy urged by the ghost of his wife thereby displaying the writer's predicament. 
The effect that exile has, not on the writers' work, but on the writers themselves seems apparently paradoxical at first. Exile appears both as a liberating experience as well as a shocking experience. The paradox is apparent because it is just a manifestation of the tension that keeps the strings attached and taut between the writer's place of origin and the place of exile. Whatever may be the geographical location of the exiled writer, in the mental landscape the writer is forever enmeshed among the strings attached to poles that pull in opposite directions. The only way the writer can rescue oneself from the tautness of the enmeshing strings is by writing or by other forms of artistic expression. The relief is only a temporary condition for no writer's work is so sharp a wedge that can snap the strings that history-makers have woven. Even if a writer consciously tries to justify one end, simultaneously, but unconsciously, there arises a longing for the other. Therein lies the fascination of exile literature.

Prominent in exile literature are the works of writers who were made to flee their countries by oppressive regimes. Two of the Russian writers namely Gorky and Solzhenitsyn form an amusing pair of victims of political exile. Gorky's works-especially his communist manifesto Mother-incited the Tsarist regime as much as what Solzhenitsyn's works-like The Gulag Archipelago - did to the Communists when they came to power. Such is the dichotomy of world politics faced by the writers. If not politics then there are racial segregation, religious discrimination, and war that force writers to flee from their countries. The First World War saw a large exodus of writers who felt that they could not write in wartime Europe as they have previously written. The Second World War saw the Nazi's persecution of the Jews. Thomas Mann wrote from his refuge in Chicago to Hermann Hesse in Germany about the uprooting and also mentioned that Europe would be a different place after the war (Simpson 227). As it turned out, the whole world became a different place as soon as Enola Gay flew over the sky of Hiroshima. What these writers benefited from their exile was freedom of speech but they could never forget the shock of their original expulsion. They always believed that it was their right to be home, yet those who were privileged to return home, were often disappointed with the changes. At home few friends remained and they missed the society of like-minded intellectuals that they had formed during the time and in the place of their exile. Once-an-exile becomes 
forever-an-exile and the works of such writers hold the verve of their restlessness.

In Kafka's short story The Departure the protagonist mentions that he can reach his goal by "getting out of here." When asked what his goal was he gives a memorable riposte: "Out of here - that's my goal" (Quoted in Simpson 96). Many writers get out of their native land because either the weather does not suit them or the society does not suit them or they just get out in search of the springs of Hippocrene for their muse. R. L. Stevenson preferred to live in Samoa because he enjoyed health in the tropics. P. B. Shelley was the quintessential radical. Even before his elopement with Mary Godwin he showed signs of his radicalism by publishing a tract called The Necessity of Atheism for which he was expelled from Oxford. Eventually the conservative English society forced him to leave England. Shelley's exile from society was so acute that in one of his letters to Mary he expressed his desire to desert all human society. He wrote, "I would retire with you and our child to a solitary island in the sea, [. . . ] and shut upon my retreat the floodgates of the world" (Quoted in Simpson 216). On the other hand Byron's was a self-exile into the continent in search of the fire to keep his muse's torch burning. He even participated in the Greek War of Independence because England did not provide him with such a stimulating atmosphere in which to write. Exile in the form of migration has been the cause of emergence of a large number of writers who have given direction to the progress of English literature. Irish-English writers like G. B. Shaw and W. B. Yeats have produced works that have become landmarks of English literature. Joyce in his novel The Portrait of an Artist as a Young Man writes: "When the soul of a man is born in this country there are nets flung at it to hold it back from flight. [. . .] I shall try to fly by those nets" (Quoted in Simpson 258). Similar was the case with American-English writers like Henry James and especially T. S. Eliot who in his poems expressed his observations about the rootlessness of modern life. As intellectual exiles from America to Europe, they were fleeing from what they perceived to be the provincialism of America and its intellectual barrenness. They fed the European sense of cultural superiority due to their restlessness and incipient exilic predicament. In this regard their exilic condition, apparently, appears to be weak when compared to that of Conrad. Joseph Conrad was born in Poland but had to spend a part of his childhood with his family exiled in northern Russia. He went 
on to seek refuge first in France and then in Britain. He knew little English till the age of twenty years, yet, when he made his home in Canterbury, Kent, in England he had a considerable amount of English works under his name. D. H. Lawrence did a bulk of his writing while traveling. Such was the case with Katherine Mansfield - first she was away from New Zealand and then she was away from England. The cases of Hemingway and Isherwood, who migrated from the continent to the New World, are still more poignant for they became distinctly established as American writers.

Internal exile is another form of exile that many writers face. Perhaps it is the most damning of all exiles for in this case the exiles stay in their own country and yet are alienated. The Russian writer Dostoevsky looks back in his autobiography on the effect of his Siberian sentence thus: "I had been cut off from society by exile and that I could no longer be useful to it and serve it to the best of my abilities, aspirations, and talents" (Quoted in Simpson 180). In fact it was the colonial powers that made most people aliens in their own country firstly through linguistic displacement. It is in this colonial context that the native writers spawned the various sub-genres of English literature. Writers like Mulk Raj Anand, R. K. Narayan, and Raja Rao, who established Indian-English literature, were all subjects of the British rule in India. Even after the colonized countries got independence, writers of many of those countries still faced a state of exile-either because of dictatorship in their countries, or because of racial persecution, or because of ethnic cleansing, or because they chose to migrate. African-English writers like Ken Saro-Wiwa, Ngugi wa Thiongo', Wole Soyinka, and Ben Okri all found themselves in some sort of exilic state.

The Indian-English writers, notably, Raja Rao became an expatriate even before the independence of the country; G. V. Desani was born in Kenya and lived in England, India, and USA; and Kamala Markandaya married an Englishman and lived in Britain (ref. Mehrotra 180, 186, 226). Nirad C. Chaudhuri preferred the English shores because his views were not readily accepted in India. Salman Rushdie's "imaginary homeland" encompasses the world over. The Iranian "fatwa" phase has added a new dimension to Rushdie's exilic condition. Colonial and post-colonial India are divisions that are now more relevant to a historian than a littérateur because Indian-English literature has transcended the barriers of petty classifications and has become almost become part of 
mainstream English literature. A major contribution in this regard has been that of the Indian writers, like Rushdie and Naipaul, who live as world citizens - a global manifestation of the exilic condition. Indian-English writers like Anita Desai, Bharati Mukherjee, Shashi Tharoor, Amitav Ghosh, Vikram Seth, Sunetra Gupta, Rohinton Mistry, Jhumpa Lahiri, and Hari Kunzru have all made their names while residing abroad. The non-resident Indian writers have explored their sense of displacement-a perennial theme in all exile literature. They have given more poignancy to the exploration by dealing not only with a geographical dislocation but also a socio-cultural sense of displacement. Their concerns are global concerns as today's world is afflicted with the problems of immigrants, refugees, and all other exiles. These exilic states give birth to the sense of displacement and rootlessness.

The Indian diaspora has been formed by a scattering of population and not, in the Jewish sense, an exodus of population at a particular point in time. This sporadic migration traces a steady pattern if a telescopic view is taken over a period of time: from the indentured labourers of the past to the IT technocrats of the present day. Sudesh Mishra in his essay "From Sugar to Masala" divides the Indian diaspora into two categories - the old and the new. He writes that:

This distinction is between, on the one hand, the semi-voluntary flight of indentured peasants to non-metropolitan plantation colonies such as Fiji, Trinidad, Mauritius, South Africa, Malaysia, Surinam, and Guyana, roughly between the years 1830 and 1917; and the other the late capital or postmodern dispersal of new migrants of all classes to thriving metropolitan centres such as Australia, the United States, Canada, and Britain. (Mishra 276)

Especially after Indian independence the Indian diasporic community has acquired a new identity due to the processes of self-fashioning and increasing acceptance by the West.

It is interesting to note that the history of diasporic Indian writing is as old as the diaspora itself. In fact the first Indian writing in English is credited to Dean Mahomed, who was born in Patna, India, and after working for fifteen years in the Bengal Army of the British East India Company, migrated to "eighteenth century Ireland, and then to England" (Kumar xx) in 1784. His book The Travels of Dean Mahomet was published in 1794. It predates by about forty years the first English 
text written by an Indian residing in India, Kylas Chunder Dutt's "imaginary history" A Journal of Forty-Eight Hours of the Year 1945 published in 1835 (ref. Mehrotra 95). The first Indian English novel, Bankimchandra Chatterjee's Rajmohan's Wife, was to be published much later in 1864. It shows that the contribution of the Indian diaspora to Indian writing in English is not new. Also interestingly, the descendants of the Indian indentured labourers in the so called "girmit colonies" have predominantly favoured writing in English, the lingua franca of the world. The likes of Seepersad Naipaul and later Shiva Naipaul, V. S. Naipaul, Cyril Dabydeen, David Dabydeen, Sam Selvon, M. G. Vassanji, Subramani, K. S. Maniam, Shani Muthoo, and Marina Budhos are significant contributors in that field.

V. S. Naipaul's characters, like Mohun Biswas from $A$ House for Mr. Biswas or Ganesh Ramsumair from The Mystic Masseur, are examples of individuals who are generations away from their original homeland, India, but their heritage gives them a consciousness of their past. They become itinerant specimen of the outsider, the unhoused, for the world to see. Their attempts at fixity are continuously challenged by the contingency of their restless existence a condition grown out of their forefathers' migration, albeit within the Empire, from India to Trinidad. Naipaul's characters are not governed by actual dislocation but by an inherited memory of dislocation. For them their homeland India is not a geographical space but a construct of imagination. Their predicament can be explained in Rushdie's words: "the past is a country from which we have all emigrated, that its loss is part of our common humanity" (12). The novels of the older generation of diasporic Indian writers like Raja Rao, G. V. Desani, Santha Rama Rau, Balachandra Rajan, Nirad Chaudhuri, and Ved Mehta predominantly look back at India and rarely record their experiences away from India as expatriates. It is as if these writers have discovered their Indianness when they are out of India. Obviously they have the advantage of looking at their homeland from the outside. The distance affords them the detachment that is so necessary to have a clear perception of their native land. In that sense, through their writing, they help to define India.

Makarand Paranjape notes "that instead of worshipping the leftovers and relics of a now inaccessible homeland as the old diaspora of indentured labourers did, the new diaspora of international Indian English writers live close 
to their market, in the comforts of the suburbia of advanced capital but draw their raw material from the inexhaustible imaginative resources of that messy and disorderly subcontinent that is India" (252). These writers record their away from India experiences and even if they look back at their homeland it is often in an elegiac tone rather than with nostalgia. Paranjape explicates this point in considering the novels of Rohinton Mistry (251). Ultimately Indian writers in the West are increasingly identifying themselves with the literary tradition of the migrant writers of the world. Rushdie says that "Swift, Conrad, Marx [and even Melville, Hemingway, Bellow] are as much our literary forebears as Tagore or Ram Mohan Roy" (20).

The modern diasporic Indian writers can be grouped into two distinct classes. One class comprises those who have spent a part of their life in India and have carried the baggage of their native land offshore. The other class comprises those who have been bred since childhood outside India. They have had a view of their country only from the outside as an exotic place of their origin. The writers of the former group have a literal displacement whereas those belonging to the latter group find themselves rootless. Both the groups of writers have produced an enviable corpus of English literature. These writers while depicting migrant characters in their fiction explore the theme of displacement and self-fashioning. The diasporic Indian writers' depiction of dislocated characters gains immense importance if seen against the geo-political background of the vast Indian subcontinent. That is precisely why such works have a global readership and an enduring appeal. The diasporic Indian writers have generally dealt with characters from their own displaced community but some of them have also taken a liking for Western characters and they have been convincing in dealing with them. Two of Vikram Seth's novels The Golden Gate and An Equal Music have as their subjects exclusively the lives of Americans and Europeans respectively.

Two of the earliest novels that have successfully depicted diasporic Indian characters are Anita Desai's Bye-Bye Blackbird and Kamala Markandaya's The Nowhere Man. These novels depict how racial prejudice against Indians in the UK of the 1960s alienates the characters and aggravate their sense of displacement. Bharati Mukherjee's novels like Wife and Jasmine depict Indians in the US - the land of immigrants, both legal and illegal - before globalization got its 
impetus. Salman Rushdie in the novel The Satanic Verses approaches the allegory of migration by adopting the technique of magic realism. The physical transformation of Gibreel Farishta and Saladin Chamcha after their fall from the bursting jumbo jet on the English Channel is symbolic of the self-fashioning that immigrants have to undergo in their adopted country. Chitra Banerjee Divakaruni in her novel The Mistress of Spices depicts Tilo, the protagonist, as an exotic character to bring out the migrant's angst. Amitav Ghosh's novel The Shadow Lines has the character lla whose father is a roaming diplomat and whose upbringing has been totally on foreign soils. She finds herself as much out of place in India as any foreigner. But when she conjures up the story of her doppelganger Magda being rescued by Nick Price from Denise, it shows the extent of her sense of rootlessness. Amit Chaudhuri in his novel Afternoon Raag portrays the lives of Indian students in Oxford. Similarly, Anita Desai in the second part of her novel Fasting, Feasting depicts Arun as a migrant student living in the suburbs of Massachusetts. The important point to note is that in a cosmopolitan world one cannot literally be a cultural and social outsider in a foreign land. There are advantages of living as a migrant - the privilege of having a double perspective, of being able to experience diverse cultural mores, of getting the leverage provided by the networking within the diasporic community, and more. But it is often these advantages that make diasporic Indians, especially of the second generation, encounter the predicament of dual identities. Such ambivalence produces existential angst in their psychology. The world simply refuses to become less complex.

The diasporic Indian writers of the first generation have already established their credentials by winning numerous literary awards and honours. But recently the ranks of the second generation of Indian writers in the West have swelled enormously and many among them have won international recognition. Meera Syal, who was born in England, has successfully represented the lives of first generation as well as second generation non-resident Indians in the West in her novels Anita and Me and Life Isn't All Ha Ha Hee Hee. Hari Kunzru in his novel Transmission traces a part of the lives of three diverse characters Leela Zahir, an actress, Arjun Mehta, a computer expert, and Guy Swift, a marketing executive - traversing through Bollywood, the Silicon Valley, and London. Sunetra Gupta has shown with candor both the unpleasantness and the 
pleasantness of intercultural relationships through characters like Moni and Niharika from her novels Memories of Rain and A Sin of Colour. Jhumpa Lahiri's book of short stories Interpreter of Maladies and her novel The Namesake convincingly illustrate the lives of both first generation and second generation Indian migrants in the US. This is possible because big issues like religious intolerance and racial discrimination are no longer the main concern of these writers. What matters now in the current world are the small things. Little, unacknowledged things gain enormous importance in changed circumstances. It is here that the differing reactions by Indian, Western, and diasporic characters towards similar situations are found to differ only superficially. It demonstrates that the inner needs of all human beings are the same. Alienation is a part of the experience of the Indian diaspora and even if people are at home in any part of the world it does not mean that they will not become victims of the sense of alienation. Increasing acceptance into the host society does not indicate that that the diasporic characters can feel at home. Social alienation is replaced by metaphysical alienation.

\section{Bibliography}

Ashcroft, Bill, Gareth Griffiths and Helen Tiffin. The Empire Writes Back. London:

Routledge, 2002.

Bhabha, Homi K. The Location of Culture. London: Routledge, 1994.

Boehmer, Elleke. Colonial and Postcolonial Literature: Migrant Metaphors, Oxford: Oxford University Press, 1995.

Chaudhuri, Amit (ed.). The Picador Book of Modern Indian Literature, London: Picador, 2001.

Dharwadker, Vinay. "Formation of Indian-English Literature" from Literary Cultures in History: Reconstructions from South Asia, Ed. Sheldon Pollack, New Delhi: Oxford University Press, 2004.

Ghosh, Amitav. "The Diaspora in Indian Culture" from The Imam and the Indian: Prose

Pieces, New Delhi: Ravi Dayal Publishers and Permanent Black, 2002.

Kumar, Amitava (ed.). Away: The Indian Writer as an Expatriate, New York:

Routledge, 2004.

Mehrotra, Arvind Krishna (ed.). An Illustrated History of Indian Literature in English.

New Delhi: Permanent Black Publishers, 2003.

Mishra, Sudesh. "From Sugar to Masala: Writing by the Indian Diaspora" from An 
Illustrated History of Indian Literature in English, Ed. Arvind Krishna Mehrotra, New Delhi: Permanent Black, 2003.

Paranjape, Makarand. "Triple Ambivalence: Australia, Canada, and South Asia in the Diasporic Imagination" from Journal of the Department of English, Volume XXXII, Numbers 1 \& 2, Eds. Sanjukta Dasgupta and Jharna Sanyal, Kolkata: Calcutta University, 2005-2006.

Rushdie, Salman. "Imaginary Homelands" from Imaginary Homelands: Essays and Criticism 1981 - 1991, London: Granta Books, 1991.

Said, Edward W. "Reflections of an Exile." Biblio: A Review of Books, Volume IV, Number 11 \& 12. Ed. Arvind N. Das. New Delhi: Brinda Datta, Nov-Dec 1999.

Simpson, John (ed.). The Oxford Book of Exile. Oxford: Oxford Univ. Press, 1995.

Writer: Amit Shankar Saha, PhD researcher in English Literature, Calcutta University. E-mail: saha.amitshankar@gmail.com. 